\title{
Third molar iatrogenic displacement to maxilary sinus: clinical case report
}

\begin{abstract}
The relationship of the maxillary posterior teeth to the maxillary sinuses has important clinical connotations. One of the main risks is the rupture or perforation of the sinus membrane (Schneider) and the projection of the tooth involved in the dental extraction and procedures of surgical extraction of the roots. Rescue of a third upper molar within the maxillary sinus requires a sufficient access area, which allows visualization and extraction with ease, for this the surgical technique of the side window Caldwell-Luc is usually the first choice. The present article shows a clinical case of displacement to the maxillary sinus by iatrogeny during the extraction of a third molar, and its surgical resolution.
\end{abstract}

Keywords: maxillary sinus, third molar, oroantral communication
Volume 8 Issue 2 - 2017

\author{
Jacobo Rivera Coello,' Gladys Reyes Torres² \\ 'Department of Maxillofacial Surgery, National Autonomous \\ University of Mexico, Mexico
}

${ }^{2}$ General Practical Dentist, Mexico

\begin{abstract}
Correspondence: Jacobo Rivera Coello, Department of Maxillofacial Surgery, National Autonomous University of Mexico, Tuxpan No. 8, interior 302, Roma Sur, Cuauhtemoc, Mexico City, Mexico, Email drjacobomaxilo@hotmail.com
\end{abstract}

Received: August 14,2017 | Published: August 29, 2017

\section{Introduction}

The maxillary sinus or also known as Highmore antrum is one of the four paranasal sinuses, which is the largest. It is a bilateral pyramidal structure located inside the maxillary body. ${ }^{1}$

\section{Physiology}

Currently the literature reports specific functions of the maxillary sinus:

a. Resonance: it works as a sound box; however, further studies are needed to analyze the alteration of phonation in the presence of aplasia or sinus hypoplasia.

b. Decrease head weight: although in cases of sinus agenesis no alterations have been reported regarding the weight of the head.

c. Cleaning, humidification and heating: The mucociliary system contributes these characteristics thanks to three components that are the mucus, the ciliary movement and the periciliary fluid that through a movement of 10 to 15 shakes / second renew the mucus present in the respiratory mucosa in an estimated time of 10-15 minutes, in order to carry bacteria and particles present in the inhaled air. Participation in the olfaction process, as well as being part of the pneumatic reserve chambers of the nostrils. ${ }^{2-8}$

\section{Anatomical relationship of maxilary sinus regarding the third molar}

One of the main risks is the tearing or perforation of the sinus membrane in procedures of dental extraction and surgical extraction of roots, in addition to the possibility of projecting during the procedure into the sinus cavity; the spread of infections of periodontal or endodontic origin and the projection of obturation material or medications towards the antrum of Highmore should be of concern. Another anatomical aspect is the proximity or roots that in some cases would result an expansion of the sinus to the alveolar process, decreasing the bone height and having repercussions for the placement of implants. ${ }^{9-15}$

\section{Displacement of third molar in sinusal cavity}

Molina VG et al. report an incidence of complications associated with third molars between $4.6-30.9 \%$ intraoperative and postoperative, of which the projection to the maxillary sinus presents less frequency in comparison with infectious processes, paraesthesia, alveolitis or bleeding. The two main causes associated with this complication are excessive force and poor surgical technique. ${ }^{16}$

\section{Diagnosis}

There are different radiographic examinations that allow the observation of a displaced tooth inside the maxillary sinus body, in which we find the occlusal radiographs, lateral cephalic, Waters radiography and first instance orthopantomography that allows to determine the relation of the third molar with the maxillary sinus, but being a two-dimensional image presents some margin of error, throwing imprecise data about the proximity of the tooth in question with the floor of the maxillary sinus, that is why, the support in a computed tomography will always be determinant; through a threedimensional image, will provide more accurate data that, in the case of displacement of third molars within the maxillary sinus, provides the exact location of the tooth and if it is accompanied by alterations in the mucosa, providing a more specific prognosis and treatment. ${ }^{17-24}$

\section{Treatment}

Some authors, such as Sverzut et al..$^{18}$ point out that it is more appropriate to use the Caldwell-Luc technique in the first surgical act, however, this act can be carried out in a second attempt, avoiding a long period of time, to avoid symptomatology. ${ }^{18}$

\section{Caldwell-Luc window}

The technique consists in raising a flap of total thickness, which generally extends from the canine to the first molar with a base in the back of the sac and with the help of a round or piezoelectric bur, a 
lateral window is made to access the maxillary sinus and to begin the exploration thereof to remove the displaced upper third molar. Once the tooth is removed, the stitches are closed and placed. ${ }^{25-35}$

\section{Clinical case}

A 26-year-old female patient with a history of having undergone surgery with an attempt to extract the left upper third molar. It presents with four days of evolution; Physical examination shows significant edema in left hemicara, erythematous teguments on the same side at the expense of inflammation, labial commissure distorted by significant manipulations during the procedure. The patient reported major headache, dysphagia, general malaise, nocturnal fever, and severe pain in the left retromolar zone. Intraorally, severe trismus is seen, pain in the mandibular movements, inflamed and dehydrated mucous membranes, ulcers in the left maxilla posterior, suture material with an entrance orifice that communicates to the sinus zone. In imaging, the left third molar is observed in the ectopic position within the maxillary sinus (Figures $1-5$ ). The patient was admitted to the hospital with a previous 24 hours of impregnation with antimicrobials, antiinflammatories and muscle relaxants. After asepsis and antisepsis, a Calwell-Luc approach was performed with osteotomy for a $2 \mathrm{~cm}$ window, removed hypertrophic mucosa, drained purulent material, And the involved tooth was located, removing it from the maxillary sinus, finishing washing and debriding the inherent mucosa. The flap closes and we move on to communication, debridging the affected mucosa and removing infected granulation tissue. The buccal flap is displaced and sealed. The surgery is terminated; the patient remains for two days with antimicrobial management and on the third day are discharged for improvement.

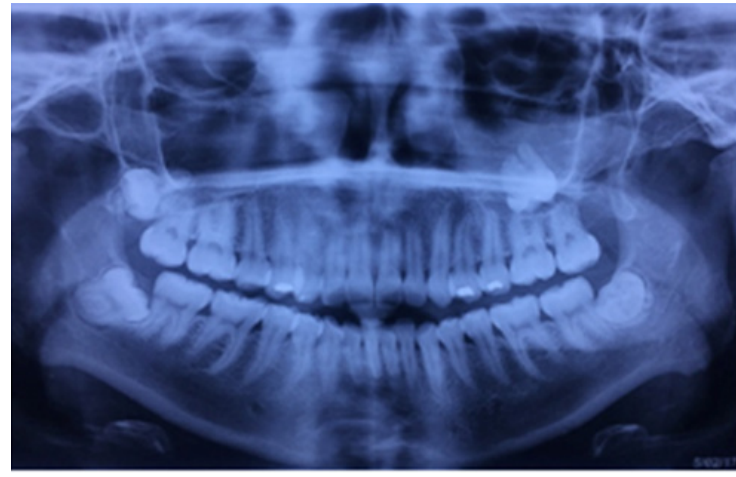

Figure I Orthopantomography showing displacement of the upper third molar.

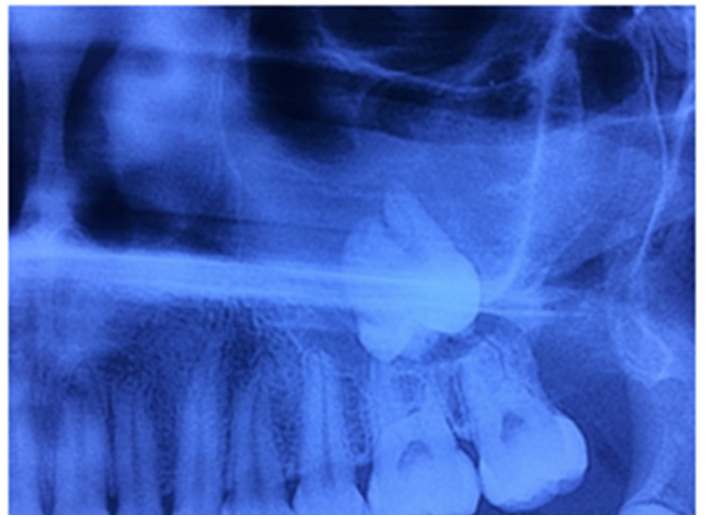

Figure 2 Approach where the third molar is observed in the sinus floor.

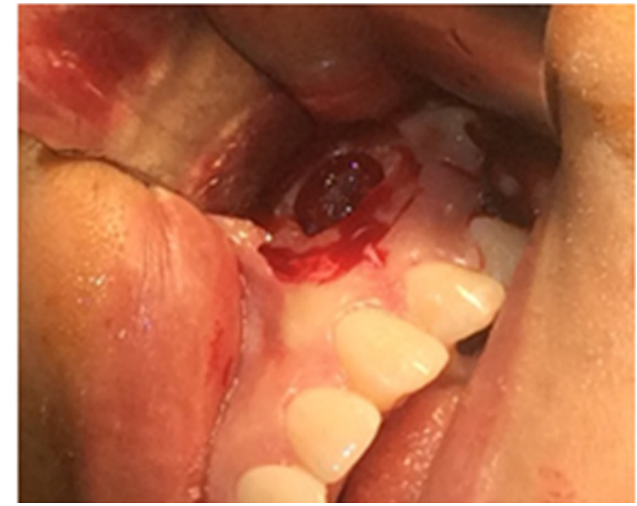

Figure 3 Approach with Calwell-Luc technique.

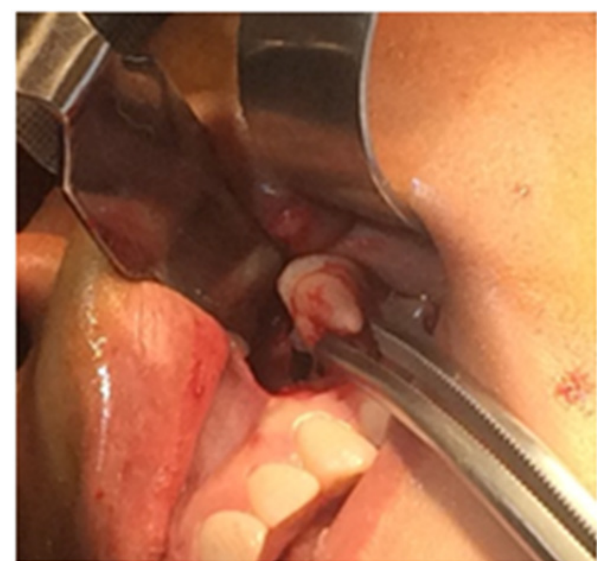

Figure 4 Rescue of the third molar inside the maxillary sinus.

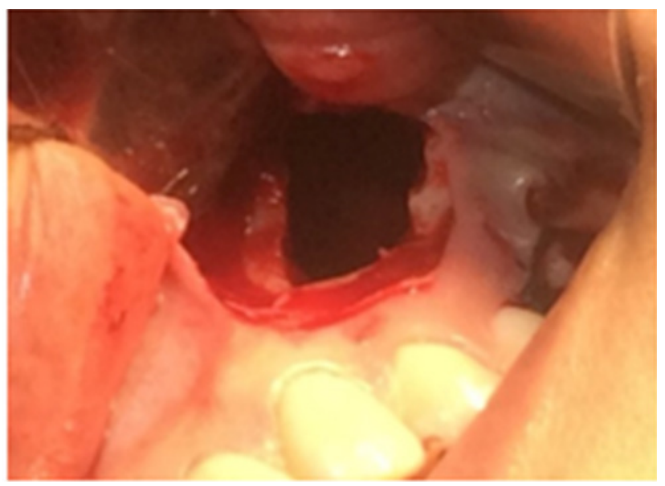

Figure 5 Management of the surgical bed. Removal of necrotic material and washing of the sinus cavity.

\section{Discussion}

Surgical extraction of third molars is a procedure that requires the anatomical knowledge and skills of the operator; the lack of knowledge is a risk factor for the complication of extraction of third molars, as well as excessive force, which is why, these procedures must be carried by the maxillofacial surgeon.

\section{Conclusion}

The projection of a third molar to the maxillary sinus is a transoperative complication that can trigger infectious processes such as sinusitis in the maxillary sinus, edema, and pain, among others. The solution of the complications presented in the clinical case was 
planned with imaging and surgical treatment, using the Calwell-Luc technique, which allows an adequate access to the sinus cavity.

\section{Funding}

None.

\section{Acknowledgments}

None.

\section{Conflicts of interest}

Author declares that there is no conflict of interest.

\section{References}

1. Von Arx T, Lozanoff L. Clinical Oral Anatomy. A Comprehensive Review for Dental Practitioners and Researchers. Switzerland: Springer International Publishing; 2017. p. 163-195.

2. Briceño JF, Estrada JH. Elevación de piso de seno maxilar: consideraciones anatómicas y clínicas. Revisión de la literatura. Univ Odontol. 2012;31(67):27-55.

3. Orrett E, Weinstock R, Friedman E. Surgical Anatomy of the Nasal Cavity and Paranasal Sinuses. Oral Maxillofac Surg Clin North Am. 2012;24(2):155-166.

4. Fragiskos D. En Oral Surgery. 8th ed, Germany: Springer; 2007. p. $181-200$

5. Wang L, Gun R, Youssef A, et al. Anatomical Study of Critical Features on the Posterior Wall of the Maxillary Sinus: Clinical Implications. Laryngoscope. 2014;124(11):2451-2455.

6. Güncü GN, Yildirim YD, Wang HL, et al. Location of posterior superior alveolar artery and evaluation of maxillary sinus anatomy with computerized tomography: a clinical study. Clin Oral Implants Re. 2011;22(10):1164-1167.

7. Kang SJ, Shin SI, Herr Y, et al. Anatomical structures in the maxillary sinus related to lateral sinus elevation: a cone beam computed tomographic analysis. Clin Oral Implants Res. 2013;24(Suppl A100):75-81.

8. Pommer B, Unger E, Süto D, et al. Mechanical properties of the Schneiderian membrane in vitro. Clin Oral Impl Res. 2009;20(6):633-637.

9. Simone F, Janner D, Dubach C, et al. Characteristics and dimensions of the Schneiderian membrane: a radiographic analysis using cone beam computed tomography in patients referred for dental implant surgery in the posterior maxilla. Clin Oral Impl Res. 2011;22(12):1446-1453.

10. Demirtas O, Harorli A. Evaluation of the maxillary third molar position and its relationship with the maxillary sinus: a CBCT study. Oral Radiol. 2016;32(3):173-179.

11. Ok E, Güngör E, Çolak E, et al. Evaluation of the relationship between the maxillary posterior teeth and the sinus floor using cone beam computed tomography. Surg Radiol Anat. 2014;36(9):907-914.

12. Gosau M, Rink D, Driemel O, et al. Maxillary Sinus Anatomy: A Cadaveric Study With Clinical Implications. The Anat Record. 2009;292(3):352-354.

13. Santamaría M, Valmaseda E, Berini L, et al. Incidence of oral sinus communications in 389 upper third molar extraction. Med Oral Patol Oral Cir Bucal. 2006;11:E334-E338.

14. Shen EC, Fu E, Chiu TJ, et al. Prevalence and location of maxillary sinus septa in the Taiwanese population and relationship to the absence of molars. Clin Oral Impl Res. 2012;23(6):741-745.

15. Hasegawa T, Tachibana A, Takeda D, et al. Risk factors associated with oroantral perforation during surgical removal of maxillary third molar teeth. Oral Maxillofac Surg. 2016;20(4):369-375.
16. Molina VG, Manzano GP. Tratamiento de desplazamientos dentarios al seno maxilar, mediante antrostomía Caldwell-Luc bajo anestesia local. Presentación de dos casos. Revista ADM. 2014;71(4):192-196.

17. Pignataro M, Mantovani M, Torretta S, et al. ENT assesament in the integrated management of candidate for (maxilary) sinus lift. Acta Otorhinolaryngol Ital. 2008;28(3):110-119.

18. Sverzut CE, Trivellato AE, Lopes LM, et al. Accidental displacement of impacted maxillary third molar: a case report. Braz Dent J. 2005;16(2):167.

19. Fugazzotto P, Vlassis J. A simplified and repair system for sinus membrane perforations. J Periodontol. 2003;74(10):1534-1541.

20. Malina J, Damerau G, Gratz K, et al. Evaluation of the maxillary sinus in panoramic radiography-a comparative study. Int $J$ Implant Dent. 2015;1(1):1-7.

21. Chan HL, Suarez F, Monje A, et al. Evaluation of maxillary sinus width on cone-beam computed tomography for sinus augmentation and new sinus classification based on sinus width. Clin Oral Impl Res. 2014;25(6):647-652.

22. Danesh S, Movahed A, ElChaar E, et al. Radiographic Evaluation of Maxillary Sinus Lateral Wall and Posterior Superior Alveolar Artery Anatomy: A Cone-Beam Computed Tomographic Study. Clin Implant Dent and Relat Res. 2017;19(1):151-160.

23. Ariji Y, Ariji E, Yoshiura K, et al. Computed tomographic indices for maxillary sinus size in comparison with the sinus volume. Dentomaxillofac Radiol. 1996;25(1):19-24.

24. Pandharbale AA, Gadgil RM, Bhoosreddy AR, et al. Evaluation of the Posterior Superior Alveolar Artery Using Cone Beam Computed Tomography. Pol J Radiol. 2016;81:606-610.

25. Jung Y, Cho B. Assessment of maxillary third molars with panoramic radiography and cone-beam computed tomography. Imaging Sci Dent. 2015;45(4):233-240.

26. Hasegawa T, Tachibana A, Takeda D, et al. Risk factors associated with oroantral perforation during surgical removal of maxillary third molar teeth. Oral Maxillofac Surg. 2016;20(4):369-375.

27. Souza K, Tavares V, Soares R, et al. Removal of an Upper Third Molar from the Maxillary Sinus. Case Reports in Dentistry 1-5.

28. Rivera J, Hernández A (2013) Comunicación oroantral. Reporte de un caso. Revista ADM. 2015;70(4):209-212.

29. Godoy E, Godoy A, Godoy P. Surgical repair oroantral fistula with a rotation and advancement palatal flap and autologous bone graft. Rev Otorrinolaringol Cir Cabeza Cuello. 2011;71(3):257-262.

30. Borgonov A, Valerio A, Favale M, et al. Surgical Options In Oroantral Fistula Treatment. Open Dent J. 2012;6:94-98.

31. Pedemonte C, Basili A, Montero S. Cierre de Fístulas Bucosinusales con Colgajo de Bola Adiposa de Bichat: Descripción de Técnica Quirúrgica y Caso Clínico. Rev Dent Chile. 2004;95(1):35-37.

32. Licéaga C, Vélez M. Colgajo lingual para cierre de fístula oronasal: aportación a la técnica. Rev esp cir oral maxilofac. 2012;34(1):31-34.

33. Chan H, Monje A, Suarez F, et al. Palatonasal Recess on Medial Wall of the Maxillary Sinus and Clinical Implications for Sinus Augmentation via Lateral Window Approach. J Periodontol. 2013;84(8):1087-1093.

34. Brook I. Sinusitis of odontogenic origin. Otolaryngology-Head and Neck Surgery. 2006;135(3):349-355.

35. Rodriguez M, Bentes R, Barros R, et al. Accidents and complications associated to third molar surgeries performed by dentistry students. Oral Maxillofac Surg. 2014;18(4):459-464. 